\title{
Angiotropic Lymphoma: An Immunophenotypically and Clinically Heterogeneous Lymphoma
}

Subramanian Yegappan, M.D., Robert Coupland, M.D., Daniel A. Arber, M.D., Nancy Wang, M.D., Ranko Miocinovic, B.S., Raymond R. Tubbs, D.O., Eric D. Hsi, M.D.

Department of Clinical Pathology (SY, NW, RM, RRT, EDH), Cleveland Clinic Foundation, Cleveland, Ohio; Department of Pathology (RC), Cross Cancer Center, Edmonton, Alberta, Canada; and Department of Pathology (DAA), City of Hope National Medical Center, Duarte, California

Angiotropic lymphoma (AL) is an uncommon lymphoma often presenting with nonspecific clinical features and having a high mortality rate. Although not specifically recognized by the Revised European-American Classification of Lymphoid Neoplasms, it likely will appear as a subtype of diffuse large B-cell lymphoma in the upcoming WHO classification. Some authors may also consider it to be a subtype of cutaneous lymphomas. Recent studies have reported an immunophenotypic heterogeneity of $\mathrm{AL}$, and in rare instances, an association with other NHL. To further characterize AL, we studied the immunophenotype by immunohistochemistry for CD5, CD10, CD20, bcl-2, and bcl-6 in 18 cases of B-cell AL identified at three medical centers in North America. Bcl-2 gene rearrangement status by polymerase chain reaction and $\mathrm{Ep}$ stein Barr virus status by in situ hybridization also were evaluated.Eight men and 10 women were identified with AL (median age 71 years). Eleven patients were diagnosed in life and seven were diagnosed at autopsy. Neurologic symptoms were the most common presentation, seen in six patients. Skin was the most commonly biopsied site. All showed classic intravascular localization; in two cases, there was also a minor diffuse large cell lymphoma component observed in some organs. Most $(89 \%)$ of the cases expressed bcl-2 protein; CD10, bcl-6 and CD5 were each expressed in $22 \%$ of cases. Based on CD5 and CD10 expression, three major groups were evident: CD5-, CD10- (11 cases); CD5+, $\mathrm{CD10}-$ ( 3 cases), and $\mathrm{CD5}-, \mathrm{CD10}+$ ( 3 cases). Even though a follicle center lymphoma preceded the AL in one patient, we did not detect bcl-2

Copyright (C) 2001 by The United States and Canadian Academy of Pathology, Inc.

VOL. 14, NO. 11, P. 1147, 2001 Printed in the U.S.A.

Date of acceptance: July 21, 2001.

Address reprint requests to: Eric D. Hsi, M.D., Head, Section of Hematopathology, Department of Clinical Pathology, L-11, Cleveland Clinic Foundation, 9500 Euclid Ave., Cleveland, OH 44195; e-mail: Hsie@ccf.org; fax: 216-444-4414. gene rearrangement in any of these cases. All cases were negative for Epstein Barr virus. Of the five treated with chemotherapy, two achieved a complete remission.Based on these findings, we conclude that ALs are clinically and immunophenotypically heterogeneous and may represent more than one pathogenetic entity. In some instances AL may be preceded by another lymphoproliferative disorder, raising the possibility that some cases of $\mathrm{AL}$ may represent a transformation from another type of lymphoma. Cutaneous manifestations of AL are common; however, it appears to be a systemic lymphoma. Although often fatal, patients with AL who are diagnosed early and treated with chemotherapy may achieve remission.

KEY WORDS: Angiotropic, Autopsy, Immunophenotype, Immunohistochemistry, Lymphoma, Mod Pathol 2001;14(11):1147-1156

Angiotropic lymphoma (AL) was first described in 1959 by Pfleger and Tappeiner as angioendotheliomatosis proliferans systemisata and considered to be of endothelial origin (1-4). Ansell et al. (5)suggested a lymphoid origin in 1982 by demonstrating surface Ig on the neoplastic cells. Subsequently, Bhawan et al. (6) and Wrotnowski et al. (7) reported leukocyte common antigen expression in 1985. The lymphoid nature was confirmed by Wick et al. (8) in 1986. Since then, other studies have demonstrated B- and T-cell monoclonality in AL (9-12). Although not specifically recognized as an entity in the Revised European-American Classification of Lymphoid Neoplasms, the European Organization for Research and Treatment of Cancer Cutaneous Lymphoma study group has proposed AL as a subtype of primary cutaneous lymphoma $(13,14)$. The WHO classification of lymphomas will probably recognize $\mathrm{AL}$ as a variant of diffuse large B-cell lymphoma (DLBCL) (15).

AL is characteristically confined to intravascular spaces, although extravascular involvement may 
occur $(8,14)$. It often involves multiple organs, but lymph nodes, spleen and bone marrow are generally spared; when these organs are involved, the pattern is diffuse rather than intravascular (16). Presenting features are nonspecific including mental status changes, skin lesions and fever; thus the diagnosis is often unsuspected and made at autopsy (17). The great majority of cases reported have been of B-cell lineage, with a few of T-cell lineage (12, 18-20). Expression of histiocytic markers, in the absence of B- and T-cell markers $(21,22)$ or clonal rearrangement has been reported in rare cases (21).

Recent studies of B-cell AL suggest the existence of distinct immunophenotypic groups $(9,11)$ and a relationship to follicle center lymphoma (FCL) (9, 23). The objective of this study was to characterize a relatively large number of B-cell AL to 1 ) describe the clinical features of these cases, and 2) determine whether distinct immunophenotypic patterns exist.

\section{MATERIALS AND METHODS}

\section{Cases}

A total of 18 B-cell AL cases from the Cleveland Clinic Foundation, Cleveland, Ohio (cases 1-6 and
16-18, 1986-2000), the City of Hope National Medical Center, Duarte, California (7-10, 1989-1997), and the Cross Cancer Center, Edmonton, Alberta (11-15, 1991-1998) were studied (Table 1). Of the 11 patients diagnosed in life, there was available follow up in eight. Autopsies were done in nine patients, with complete reports and slides available in five patients. Patients 1 to 3 and 18 have been reported previously (24-27).

\section{Immunohistochemistry and Molecular Studies}

Paraffin immunohistochemistry for CD3 (Zymed, South San Francisco, CA, predilute), CD5 (Novocastra, New Castle upon Tyne, UK, 1:10), CD10 (Novocastra, 1:5), CD20 (DAKO, Carpinteria, CA, 1:50), cyclin D1 (Novocastra, 1:10), bcl-2 (Ventana Medical Systems, Tuscon, AZ, predilute) and bcl-6 (Santacruz Biotechnology, Santa Cruz, CA, 1:20) was performed (with appropriate controls) in all cases using an automated immunostainer (Ventana Medical Systems) (28).

Polymerase chain reaction (PCR) for the $t(14 ; 18)$ translocation was done using DNA extracted from paraffin-embedded tissues in Cases 1 to 6 and 11 to 18 with major breakpoint region primers according

TABLE 1. Clinical and Immunophenotypic Features of 18 Patients with B-cell Angiotropic Lymphoma

\begin{tabular}{|c|c|c|c|c|c|c|}
\hline Number & Age/Sex & Clinical History & Diagnostic Site & Treatment & Follow-Up & Immunophenotype \\
\hline 1 & $69 \mathrm{~F}$ & $\begin{array}{l}\text { Lower extremity } \\
\text { weakness } \times 6 \text { mo }\end{array}$ & Autopsy $^{a}$ & Steroids & - & CD20, Bcl-2 \\
\hline 2 & $67 \mathrm{M}$ & $\begin{array}{l}\text { Lower extremity } \\
\text { weakness } \times 7 \text { mo }\end{array}$ & Sural nerve & Chemotherapy & ANED 9 mo & CD20, Bcl-2, CD10 \\
\hline 3 & $46 \mathrm{~F}$ & $\begin{array}{l}\text { Multiple episodes of } \\
\text { sensorimotor deficits } \\
\times 1 \text { year }\end{array}$ & Autopsy $^{a}$ & Steroids & - & CD20, Bcl-2, CD5, CD10 \\
\hline 4 & $72 \mathrm{~F}$ & $\begin{array}{l}\text { Transient neurologic } \\
\text { symptoms, seizures } \\
\text { ×2 weeks }\end{array}$ & Brain, frontal lobe & Palliative & DOD $1 \mathrm{mo}$ & CD20, Bcl-2 \\
\hline 5 & $66 \mathrm{M}$ & $\begin{array}{l}\text { Pleural effusion, acute } \\
\text { renal failure } \times 1 \text { mo }\end{array}$ & Autopsy $^{a}$ & None & - & CD20, Bcl-2 \\
\hline 6 & $79 \mathrm{~F}$ & Skin lesion & Skin, lower limb & $\begin{array}{l}\text { Chemotherapy initially } \\
\text { and at relapse }\end{array}$ & $\begin{array}{l}\text { Relapse at } 24 \mathrm{mo} \text {, } \\
\text { ANED } 30 \mathrm{mo}\end{array}$ & CD20, Bcl-2, CD5, Bcl-6 \\
\hline 7 & $77 \mathrm{~F}$ & NA & Skin, lower limb & NA & NA & CD20, Bcl-2, CD5, Bcl-6 \\
\hline 8 & $82 \mathrm{~F}$ & NA & Skin, abdomen & NA & NA & CD20, Bcl-2, Bcl-6 \\
\hline 9 & $68 \mathrm{M}$ & $\begin{array}{l}\text { Anemia, } \\
\text { thrombocytopenia }\end{array}$ & $\mathrm{BM}$ & NA & NA & CD20, Bcl-2 \\
\hline 10 & $57 \mathrm{~F}$ & "Brain infarcts" & Autopsy $^{b}$ & None & - & CD20, Bcl-2 \\
\hline 11 & $71 \mathrm{M}$ & Fever, dyspnea $\times 3$ mo & Autopsy $^{b}$ & None & - & CD20, Bcl-2, CD10 \\
\hline 12 & $80 \mathrm{M}$ & $\begin{array}{l}\text { Multiorgan failure } \times 1 \\
\text { week }\end{array}$ & Autopsy $^{b}$ & None & - & CD20 \\
\hline 13 & $71 \mathrm{~F}$ & Jaundice & Liver $^{b}$ & Chemotherapy & DOD $5 \mathrm{mo}$ & CD20, Bcl-2 \\
\hline 14 & $90 \mathrm{M}$ & Urinary obstruction & Prostate & None & DWD 2 mo & CD20, Bcl-2, Bcl-6, CD5 \\
\hline 15 & $63 \mathrm{~F}$ & NA & $\mathrm{BM}$ & None & DOD 13 mo & CD20, Bcl-2 \\
\hline 16 & $62 \mathrm{M}$ & $\begin{array}{l}\text { Multiple febrile } \\
\text { episodes } \times 10 \text { mo }\end{array}$ & Autopsy $^{a}$ & $\begin{array}{l}\text { Chemotherapy } 4 \\
\text { months before death }\end{array}$ & $\begin{array}{l}\text { DOD } 14 \text { mo after } \\
\text { PB evaluation }\end{array}$ & CD10 \\
\hline 17 & $71 \mathrm{~F}$ & $\begin{array}{l}\text { Lower limb weakness } \\
\quad \times 3 \text { mo }\end{array}$ & T10 vertebra ${ }^{a}$ & Steroids & DOD $0.5 \mathrm{mo}$ & CD20, Bcl-2 \\
\hline 18 & $71 \mathrm{M}$ & $\begin{array}{l}\text { Multiple skin lesions } \\
\times 9.75 \text { years, } \\
\text { hepatomegaly }\end{array}$ & Skin, liver & $\begin{array}{l}\text { PUVA at presentation; } \\
\text { chemotherapy at } 3 \\
\text { relapses }\end{array}$ & $\begin{array}{l}\text { Lost to follow-up } \\
1 \text { year after } 4^{\text {th }} \\
\text { relapse }(9.75 \mathrm{yr})\end{array}$ & CD20, Bcl-2 \\
\hline
\end{tabular}

${ }^{a}$ Autopsies with complete report.

${ }^{b}$ Autopsies with incomplete report.

NA, not available; BM, bone marrow; PB, peripheral blood; DOD, died of disease; ANED, alive, no evidence of disease; AWD, alive with disease; PUVA, psoralens and ultraviolet light-A. 
to previously published methods (28). Epstein Barr virus status by in situ hybridization (EBER-ISH) was done in all cases following established protocols (29). A poly dT probe was used to assess RNA integrity.

DNA was extracted from 5-micron paraffin sections of involved splenectomy and autopsy renal tissue from Patient 16 using the Qiagen tissue kit (Valencia, CA). Immunoglobulin heavy chain gene rearrangement (IgH) PCR studies were performed, as previously described (30), with the following primers sets directed against the framework III and the joining regions of the IgH gene: VLJHA 5'-CAC CTG AGG AGA CGG TGA CC-3'; FRIIIA 5'-ACA CGG $\mathrm{C}(\mathrm{C} / \mathrm{T})(\mathrm{G} / \mathrm{C}) \mathrm{TGT}$ ATT ACT GT-3'. The primers were labeled with fluorescent dyes (Applied Biosystems, Foster City, CA) and the PCR products were separated on the ABI 310 Genetic Analyzer (Applied Biosystems). The PCR products were size electrophoresed on a $15 \%$ polyacrylamide gel, and clonal bands were purified using the Qiaex kit (Qiagen). The purified DNA was sequenced by using the BigDye terminator sequencing system (Applied Biosystems).

\section{RESULTS (Table 1)}

\section{Clinical}

Of the 18 patients, eight were male (62-90 years) and 10 were female (46-82 years), with a median age of 71 and a mean of 70 years. The most common clinical features were neurologic (6 patients: $1-4,10,17)$ and cutaneous (4 patients: 6-8, 18). Less commonly patients presented with dyspnea, anemia, thrombocytopenia, fever, jaundice, hepatomegaly, multiorgan failure and urinary obstruction. Eleven patients were diagnosed in life and seven were diagnosed at autopsy. Of the patients diagnosed during life, the most frequently biopsied site was the skin (4). Other biopsied sites were liver (2, one of whom also had skin biopsies), bone marrow (2), brain, sural nerve, prostate, and vertebral body.

Regarding treatment, five patients were treated with chemotherapy, two $(2,6)$ of whom have been in complete remission 9 and 30 months post-therapy; two $(16,13)$ died at 4 and 5 months. Patient 18 survived for 9.75 years with recurrent skin lesions and multiple chemotherapy treatments, but was then lost to follow-up (slides from the initial diagnosis of "reactive angioendotheliomatosis" were not available for this study). Three patients $(4,14$, and 15) who received no chemotherapy died at 1,2 , and 13 months after diagnosis. Three patients had no available follow-up. The remaining seven had AL diagnosed at autopsy. In 5 patients diagnosed at autopsy, symptoms were present 1 week to 14 months before death. The clinical data are summarized in Table 1.

\section{Histopathology}

$H \& E$ sections in all cases demonstrated intravascular lymphoma that involved capillaries, veins, and small arterioles. The cells in each case were large with scant-to-moderate amounts of cytoplasm. The nuclei were usually round with open chromatin and multiple small nucleoli. Immunoblastic cells were not a prominent feature of these lymphomas. Representative cases are illustrated in Figures 1 and 2.

Complete autopsy results, available in five patients, showed widespread involvement of the brain, adrenals, kidneys and lungs in all patients, and of liver, pancreas, thyroid, parathyroid, spleen, lymph nodes, GI tract, heart, prostate, ovary and uterus in some patients (Table 2).

Three patients are discussed in detail because of their instructive features. Patient 16 presented with multiple febrile episodes. The white blood count was $10.4 \times 10^{9} / \mathrm{L}$ with $28 \%$ "atypical" lymphocytes. Unfortunately, the blood smear was not available for review. Flow cytometry demonstrated a CD19+, CD23+, CD5-, kappa light chain restricted population. A bone marrow biopsy showed a rare nonparatrabecular lymphoid aggregate of small and occasional large cells. This was interpreted as a low grade B-cell lymphoproliferative disorder and treatment was not considered at this time. A CD20 immunostain (performed for this study) showed small and occasional large B-cells in the aggregate and a rare sinusoid containing B-cells that was not visible on hematoxylin and eosin sections. His systemic symptoms worsened and splenomegaly became evident 10 months after initial presentation. A splenectomy was performed that revealed a diffuse proliferation of predominantly small lymphoid cells with condensed chromatin principally in the splenic red pulp and sinuses. Again, this was interpreted as a low-grade lymphoma. Despite this, the patient was treated with adriamycin-based multiagent chemotherapy but died 4 months later. At autopsy there was conventional B-cell AL in multiple organs including brain, kidney, adrenal, lymph nodes, GI tract, prostate and lung, with unequivocal cytologic features of a large cell lymphoma. Figure 3 illustrates the bone marrow, spleen, and kidney findings.

Patient 17 presented with a 3-month history of lower extremity weakness. The past medical history included carcinomas of the colon and breast 11 and 8 years before this time, respectively. MRI showed multiple nodules in the leptomeninges, vertebral bodies and nerve roots, clinically consistent with metastatic carcinoma. A 10th thoracic vertebral bi- 


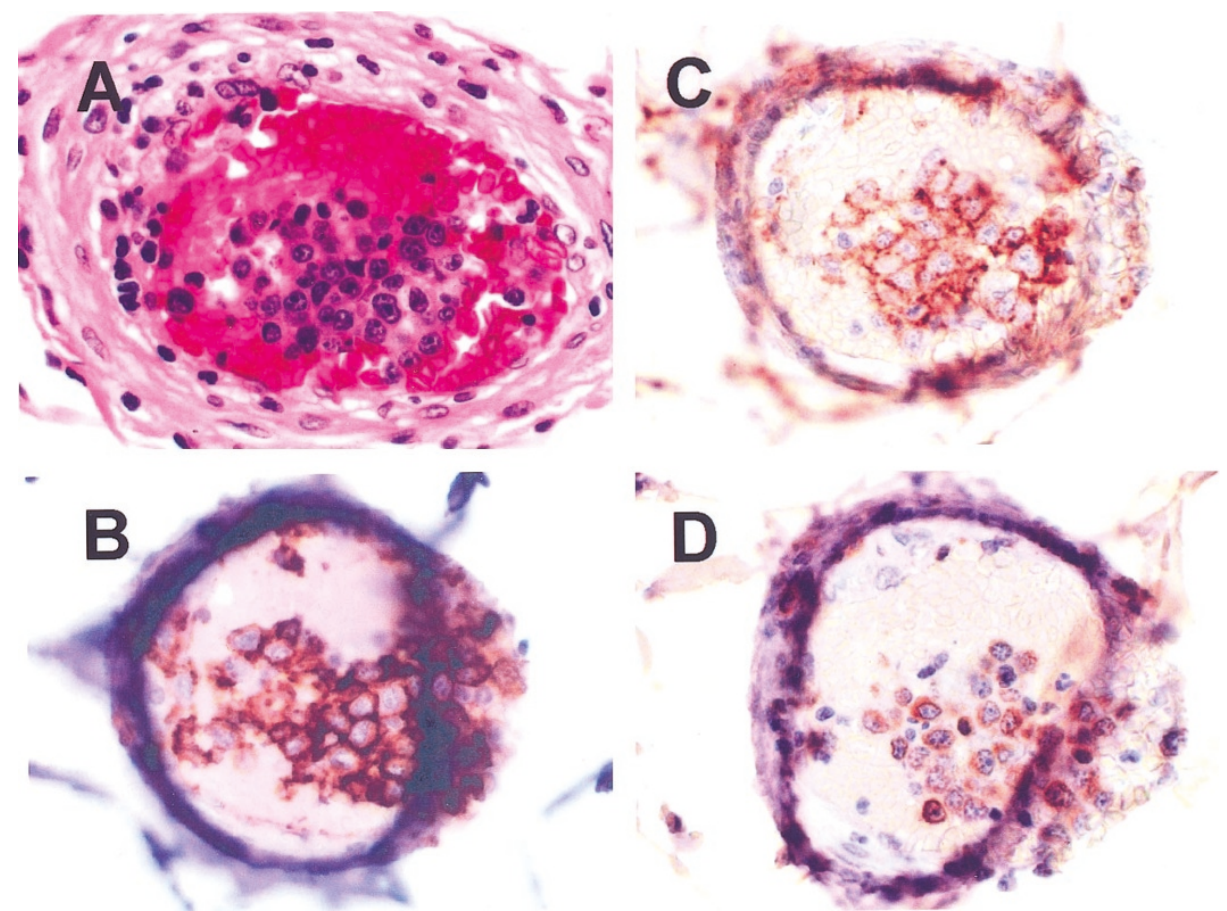

FIGURE 1. Case 2. Example of AL demonstrating a CD20+, CD10+, bcl-2+ phenotype. A, H\&E; B, CD20 immunostain; C, CD10 immunostain; D, bcl-2 immunostain.
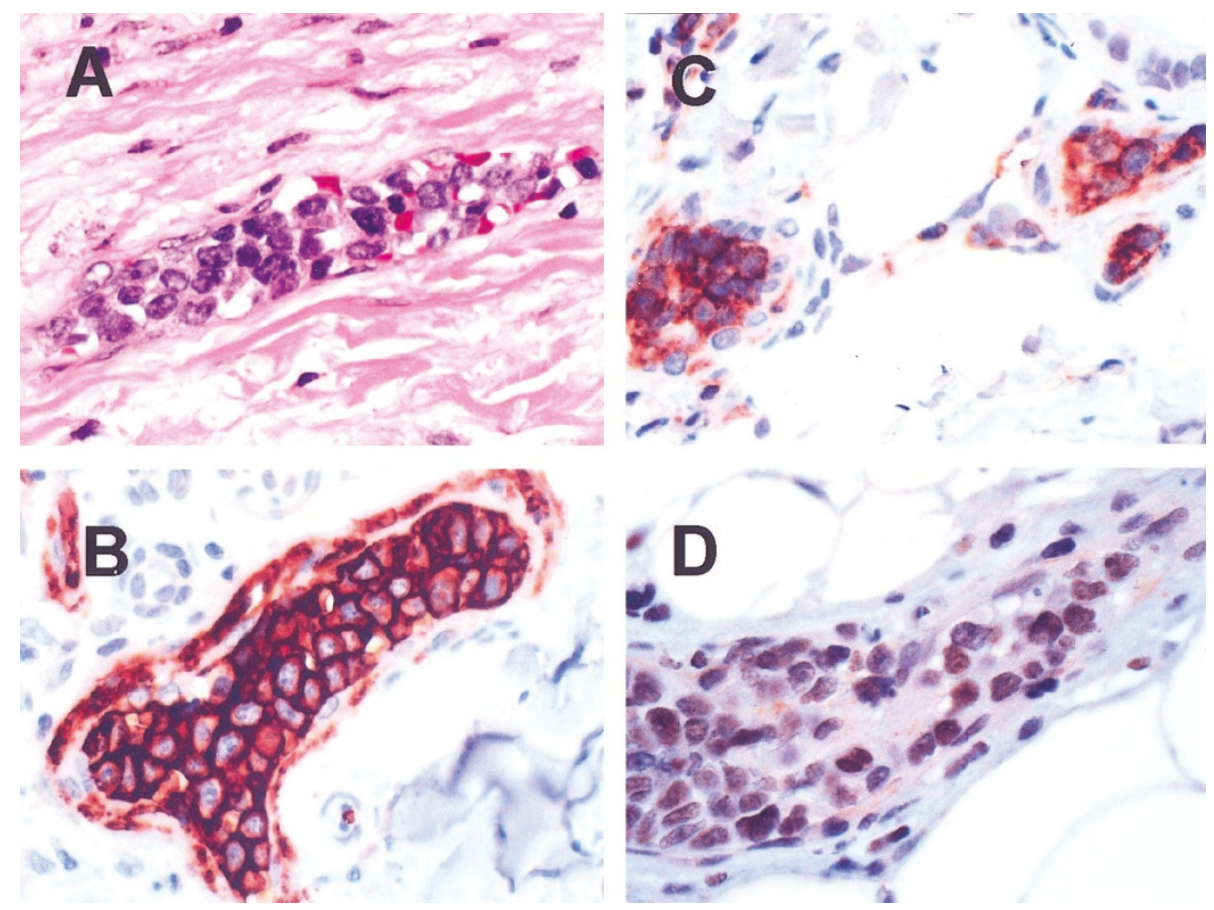

FIGURE 2. Case 7. Example of AL showing expression of CD20, CD5, and bcl-6. A, H\&E; B, CD20 immunostain; C, CD5 immunostain; D, bcl-6 immunostain.

opsy showed an intravascular (minor) as well as an extravascular proliferation of intermediate to large atypical CD20 + B-cells. Chemotherapy was not an option because of her poor general condition and the patient died 2 weeks later. At autopsy there was multiorgan involvement by B-cell AL in the brain, kidney, adrenal, heart, and lung. In the left atrial subendocardium, a $2 \times 1 \mathrm{~cm}$ nodule showing extravascular involvement was also found.

Patient 11 presented 21 months before death with a stage I FCL, grade 1 . He was treated with local radiation and attained a complete remission. 


\begin{tabular}{|c|c|c|c|c|c|}
\hline \multirow{2}{*}{ Organ } & \multicolumn{5}{|c|}{ Patient } \\
\hline & 1 & 3 & 5 & 16 & 17 \\
\hline Brain & $\mathrm{NE}$ & + & + & + & + \\
\hline Adrenal & + & + & + & + & + \\
\hline Kidney & + & + & + & + & + \\
\hline Lung & + & + & + & + & + \\
\hline GU & + & + & + & + & - \\
\hline GI & + & + & - & + & - \\
\hline Heart & - & + & + & - & + \\
\hline Liver & + & - & + & - & - \\
\hline Pancreas & - & + & + & - & - \\
\hline Spleen & - & - & + & $+1-a$ & - \\
\hline Lymph node & - & - & + & + & - \\
\hline Thyroid/parathyroid & - & + & - & - & - \\
\hline
\end{tabular}

${ }^{a}$ Involved at splenectomy during life (see Results).

NE, not examined.

Eighteen months later he developed unexplained fevers and dyspnea with a negative radiologic examination, bone marrow biopsy, and liver biopsy. He died 3 months later. Autopsy revealed multiorgan involvement by B-cell AL, without evidence of a recurrent FCL.

\section{Immunohistochemistry (Table 1)}

All cases were negative for CD3 and cyclin D1; 17/18 expressed CD20. Case 16 was CD20, CD79a and CD3 negative, but expressed CD45RB. A B-cell lineage was assumed from the previous flow cytometric and genotypic studies (above). Sixteen (89\%) cases expressed bcl-2. Ten (56\%) cases were negative for CD5, CD10, and bcl-6 expression. Four cases (22\%) each expressed CD5, bcl-6, and CD10. Bcl-6 and CD5 were coexpressed in three (17\%) and, CD5 and CD10 in one case. No case coexpressed CD5, CD10 and Bcl-6.

\section{PCR, EBER-ISH, DNA Sequencing}

The $t(14 ; 18)$ was not detected by PCR using major breakpoint region primers in the 14 cases tested (1-6, 11-18). All 18 cases were negative for EBER. PCR of the splenectomy and autopsy renal samples from Patient 16 for IgH gene rearrangement revealed identically sized (116 base pair) products, supporting identical clones in the different samples. DNA sequencing of these products showed identical sequences, confirming clonal identity.

\section{DISCUSSION}

B-cell AL, a rare subset of DLBCL, often is diagnosed at autopsy because the clinical features are nonspecific. There is a notable absence of lymphadenopathy, splenomegaly or circulating lymphoma cells in the majority of cases. These factors contribute to a delayed diagnosis, misdiagnosis or both. The most common presenting features are neurologic, seen in approximately two-thirds of patients (31). Neurologic manifestations include progressive multifocal cerebrovascular events, spinal cord and nerve root vascular syndromes, subacute encephalopathy, and peripheral and cranial neuropathies (31). Cutaneous manifestations are also common and often consist of hyperpigmented or hemorrhagic lesions on the thighs and abdomen (31). However, patients can present with numerous other signs and symptoms, including fever, hepatomegaly, urinary obstruction, renal failure, adrenomegaly and dyspnea.

Most previous series of AL are relatively small (fewer than 10 cases) and detailed immunophenotypic features are lacking $(8,18,31-35)$. To better characterize these cases and determine whether common immunophenotypic patterns can be discerned, we report a multicenter series of B-cell AL using paraffin-section immunohistochemistry for markers commonly used in lymphoma diagnosis. As seen in other large series, patients tended to be older adults with varied clinical presentations (31). The male to female ratio was 0.8 , within the 0.7 to 5.0 range seen by others $(8-10,18,31,32,35-37)$. Thirty-nine percent of our cases were not diagnosed until autopsy. Consistent with prior literature, common clinical findings were referable to neurologic and cutaneous involvement (31). However, other presentations occurred including cytopenias, organomegaly, jaundice, and urinary obstruction. All cases were B-cell lymphomas. A T-cell phenotype, although reported previously, was not seen $(19,20,38-40)$.

In keeping with the systemic nature of AL, autopsies revealed involvement of brain, lung, kidney, and adrenal gland in all patients, while liver, pancreas, GI tract, spleen, lymph node, ovary, prostate, heart, thyroid, and parathyroid glands were less commonly involved (Table 2). This reflects the findings in the literature where brain (92-100\%), kidney (17-100\%), adrenal (33-79\%), lung (33-100\%), heart 

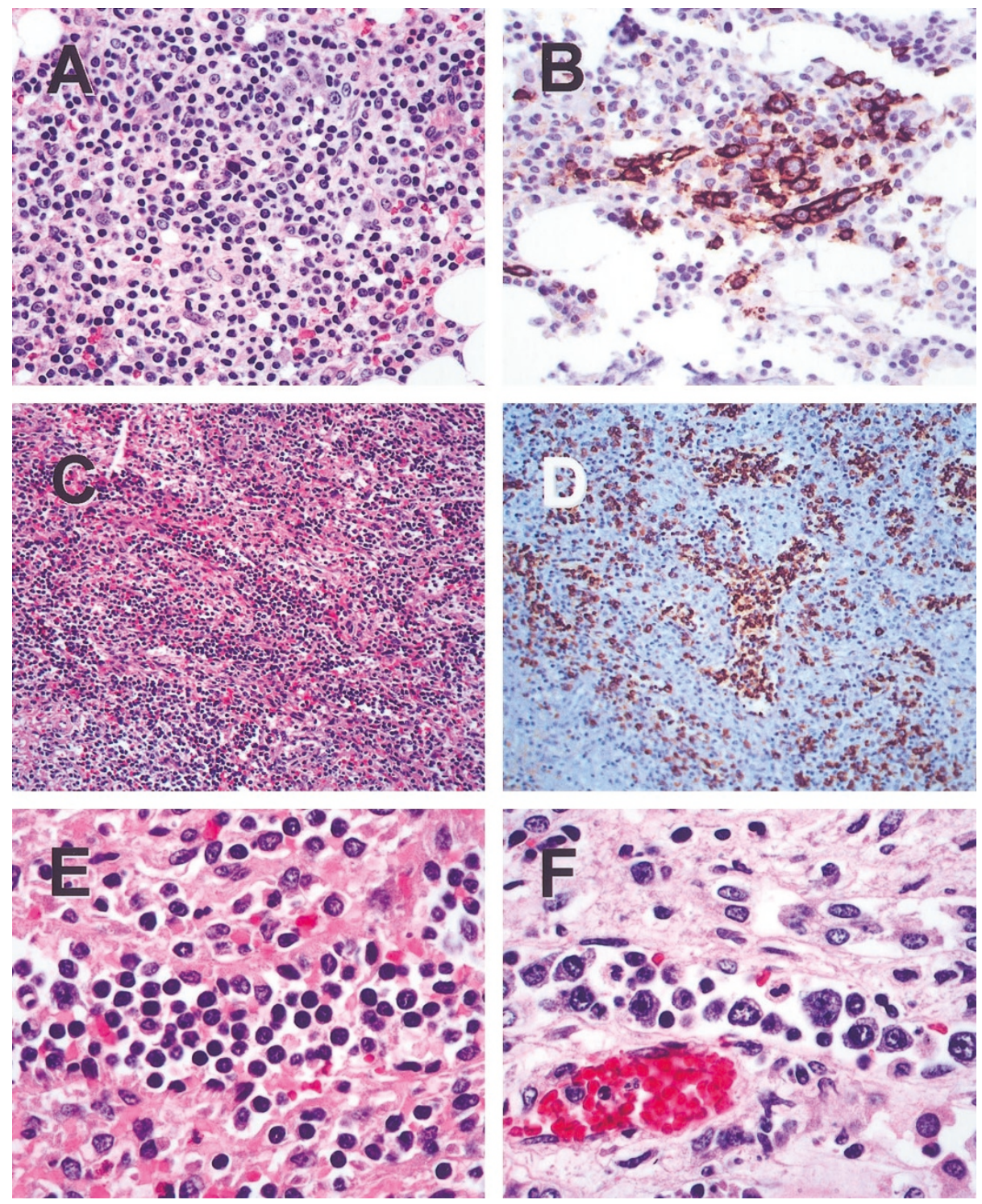

FIGURE 3. Case 16. A, Bone marrow during life showing a lymphoid aggregate of predominantly small cells. B, CD20 immunostain highlighting intrasinusoidal B-cells not readily apparent on H\&E stain. C, H\&E stain of splenectomy specimen showing red pulp infiltration by lymphoid cells. D, CD20 immunostain of spleen showing the sinusoidal distribution of the B-cells. E, High magnification of the splenectomy specimen demonstrating small lymphocytes within splenic sinusoids. F, Autopsy renal tissue showing AL at same magnification as $\mathbf{E}$. The cells are transformed with vesicular chromatin and small nucleoli. Panels $\mathbf{E}$ and $\mathbf{F}$ are at identical magnification $(1000 \times)$.

(17-64\%), spleen (17-50\%), lymph node (17-46\%), liver (33-64\%), GI tract (25-62\%), and GU system (17-80\%) showed evidence of AL $(8,31,32)$.

The majority of cases expressed bcl-2 protein. This marker has been shown to be an indicator of poor prognosis in nodal DLBCL (41), in keeping with the poor prognosis of most patients with AL. However, the utility of bcl-2 expression in subtyping nodal NHL is limited (42). Bcl-6 protein is expressed in the vast majority of FCL but also appears to be present in a majority of DLBCL $(43,44)$. Only four of our AL cases expressed bcl- 6 protein. Thus the percentage of AL cases expressing bcl- 6 protein appears less than in typical DLBCL. The significance of this finding, if any, is unknown. Bcl-6 protein expression has been suggested to be a marker of germinal center origin $(45,46)$, but it does not appear to be specific $(47,48)$. In fact, the use of this protein expression status to predict a germinal center origin in large cell lymphomas has been called into question (43). A recent report by Zhang and colleagues suggests that low bcl-6 protein expression might be associated with a short disease-free survival in DLBCL (49). In our series of B-cell AL there appear to be no distinguishing features of the bcl- 6 positive cases, although the number of cases is relatively small.

Regarding CD5 and CD10 expression, we saw a heterogeneous pattern that could be divided into three major groups, similar to other reports of DLBCL $(9,48)$. Group one (three cases: $2,11,16)$ includes the $\mathrm{CD} 10+/ \mathrm{CD} 5-$ lymphomas. Interest- 
ingly, one of these cases occurred in a patient with a prior history of a FCL. Although we could not determine whether these two lymphomas had a common clonal origin, the expression of CD10 is consistent with the hypothesis that these are related to FCL. Previous reports (23) demonstrate that rare cases of AL can occur after FCL and may represent an unusual form of large cell transformation/ progression. Group two (three cases: 6, 7, 14) was composed of CD5+/CD10- lymphomas. As suggested in de novo CD5-positive diffuse large cell lymphoma, these B-cell ALs may derive from a subset of CD5 expressing cells distinct from chronic lymphocytic leukemia or mantle cell lymphoma $(9$, 50 ). None of the patients in this study had a history of chronic lymphocytic leukemia or mantle cell lymphoma. Group three was the largest group and was comprised of the CD5-/CD10 - cases (11), similar to the findings in non-angiotropic large B-cell lymphomas (48).

One case (Case 3) was unusual in that both CD5 and CD10 were expressed. In our experience with nodal large cell lymphomas using flow cytometry, this is unusual and the significance of this finding, if any, is unknown. It may represent a phenotypic aberrancy often seen in malignant cells, analogous to what is seen in acute leukemias (51). One recent report of the immunophenotype of diffuse B-cell lymphomas using flow cytometry noted a relatively high percentage of phenotypic aberrancy, including CD5 and CD10 coexpression (52). However, this does not appear to be the collective experience of others (13).

The $t(14 ; 18)$ seen in most FCL was not detected in any of the tested specimens using primers to the major breakpoint region. The sensitivity of our assay is approximately one in 10,000 cells. Thus, it appears that the majority of cases of AL are not related to FCL. However, we acknowledge the fact that we may indeed be missing cases with a $t(14 ; 18)$ because we did not analyze for the other breakpoints. In fact, the one case with a history of FCL was also negative; however, the original lymphoma was also negative for the translocation by PCR using major breakpoint region primers (data not shown). Likewise, Epstein Barr virus (EBV) was absent in our cases by EBER-ISH. This is in agreement with the series of Kanda et al. in which, although EBV was detected by PCR, EBER-ISH showed that the lymphoma cells were not the source of EBV (10). Similarly, Bergmann and colleagues did not detect EBV in their small series of central nervous system AL (53). EBV has been detected in AL but usually in immunocompromised patients or in T-cell $\mathrm{AL}$ (54-56).

Two points are worth emphasizing. First, B-cell AL can be associated with or preceded by a lymphoproliferative disorder (mostly large cell lym- phoma) in up to one-third of cases $(4-6,23,31$, 56-58). It is uncertain whether the two lymphomas are related or not because clonality studies comparing them have not been performed. In one of our patients (17) there was an extravascular DLBCL diagnosed on vertebral biopsy; however, the predominant pattern almost everywhere else at autopsy was AL. On retrospective analysis, the diagnostic vertebral body biopsy did show a minor intravascular component. Because the patient died within 2 weeks, we believe that these two processes are the same. This, along with finding a focus of DLBCL in the heart at autopsy, would support considering AL as part of the spectrum of DLBCL, as is proposed in the upcoming WHO classification (15). Patient 16 carried a diagnosis of a CD5-negative low-grade lymphoproliferative disorder that was ill-defined. The bone marrow contained small B-cells as well as scattered large B-cells and was not clearly a DLBCL. The spleen was also difficult to classify. It contained an unusual red-pulp and sinusoidal distribution with predominantly small B-lymphocytes. The autopsy, however, demonstrated extensive AL with a more conventional large cell cytology. The finding of identical IgH rearrangements by PCR and sequencing favors the interpretation that these are manifestations of one and the same lymphoma, perhaps in the process of transforming from a low to high grade process over a period of 4 months. Of the low grade NHLs, FCL and gastric MALT-type lymphoma have been reported in rare patients with B-cell AL $(23,37)$. Case 11 had a grade I FCL 21 months before B-cell AL. Both lymphomas expressed bcl-2 and CD10 but not bcl-6. Both lacked bcl-2 gene rearrangement. Cases such as these raise the possibility that B-cell AL, in some instances, represents a transformation from a lower grade process and hint at a histogenetic diversity similar to that proposed for other lymphomas such as T-cell rich B-cell large cell lymphoma (59). Further studies must be done to definitively demonstrate clonal relatedness.

Second, although AL has a poor prognosis, some patients may respond to appropriate multiagent chemotherapy. DiGiuseppe and colleagues reported a series of 10 patients with AL, four of whom were treated with combination chemotherapy with encouraging results (18). These authors also review numerous prior studies demonstrating a complete remission rate of $43 \%$. More recently Calamia and colleagues and Kanda et al. report a favorable response to chemotherapy $(10,60)$. Autologous bone marrow transplantation (at relapse) has also been successful in a single case report (61). In our series, two of the five patients $(2,6)$ treated with chemotherapy achieved a complete remission. One is alive without disease at 30 months having been treated for a relapse. Patient 18 illustrates that multiple 
relapses can be successfully managed with chemotherapy. Thus, AL patients, when treated early and aggressively have the potential for achieving a durable remission. As suggested by BogomolskiYahalom et al., we agree that it is unknown whether the poor survival of AL is due to the failure to diagnose and properly treat patients or due to biologic features intrinsic to this unusual type of lymphoma (57). Some clues to the pathogenesis and biologic behavior of this lymphoma may be found by further study of adhesion molecule expression $(10,32,37,39)$. Despite the generally recognized aggressive clinical behavior of AL, it appears that a prolonged course can occur, as demonstrated by Patient 18 (35, 62).

In summary, B-cell AL is a heterogeneous disorder with a myriad of clinical presentations. There continues to be a high mortality; however, treatment successes do occur with multiagent chemotherapy. Patients may have pre-existing or coexisting lymphoproliferative disorders raising the possibility that, at least in some cases, AL is a transformation of a lower grade process, confirmed by sequencing in one of our cases. EBV infection appears to play no role in this lymphoma. Although most cases express bcl-2 protein, they lack the $t(14$; 18). Immunophenotypically, these cases are also heterogeneous and can be divided into three major groups based on CD5 and CD10 expression. The significance of such a division is uncertain but may have relevance as more is learned regarding the pathogenesis of this unusual form of lymphoma. The above findings seem to suggest that, at this time, AL may not be a single discrete entity with a single pathogenetic, phenotypic, and molecular genetic profile (much like DLBCL). Despite the inadequacies of evolving classification systems, AL does occur and clinicians and pathologists must be aware of AL to make earlier diagnoses.

Acknowledgment: We gratefully acknowledge the help of Randa Alsabeh, MD, Cedars-Sinai Medical Center, Los Angeles, CA in obtaining clinical history.

\section{REFERENCES}

1. Pfleger L, Tappeiner J. Zur Kenntnis der systemisierten Endotheliomatose der cutanen Blutgefabe (Reticuloendotheliose?). Hautarzt 1959;10:359-63.

2. Braverman IM, Lerner AB. Diffuse malignant proliferation of vascular endothelium. A possible new clinical and pathological entity. Arch Dermatol 1961;84:72-80.

3. Haber H, Harris-Jones JN, Wells AL. Intravascular endothelioma (endothelioma in situ, systemic endotheliomatosis). J Clin Pathol 1964;17:608-11.

4. Scott PW, Silvers DN, Helwig EB. Proliferating angioendotheliomatosis. Arch Pathol 1975;99:323-6.

5. Ansell J, Bhawan J, Cohen S, Sullivan J, Sherman D. Histiocytic lymphoma and malignant angioendotheliomatosis: one disease or two? Cancer 1982; 50:1506-12.
6. Bhawan J, Wolff SM, Ucci AA, Bhan AK. Malignant lymphoma and malignant angioendotheliomatosis: one disease. Cancer 1985;55:570-6.

7. Wrotnowski U, Mills SE, Cooper PH. Malignant angioendotheliomatosis. An angiotropic lymphoma? Am J Clin Pathol 1985; 83:244-8.

8. Wick MR, Mills SE, Scheithauer BW, Cooper PH, Davitz MA, Parkinson K. Reassessment of malignant angioendotheliomatosis. Evidence in favor of its reclassification as intravascular lymphomatosis. Am J Surg Pathol 1986;10:112-23.

9. Estalilla OC, Koo CH, Brynes RK, Medeiros LJ. Intravascular large B-cell lymphoma. A report of five cases initially diagnosed by bone marrow biopsy. Am J Clin Pathol 1999;112: 248-55.

10. Kanda M, Suzumiya J, Ohshima K, Tamura K, Kikuchi M. Intravascular large cell lymphoma: clinicopathological, immuno-histochemical and molecular genetic studies. Leuk Lymphoma 1999;34:569-80.

11. Khalidi HS, Brynes RK, Browne P, Koo CH, Battifora H, Medeiros LJ. Intravascular large B-cell lymphoma: the CD5 antigen is expressed by a subset of cases. Mod Pathol 1998; 11:983-8.

12. Lakhani SR, Hulman G, Hall JM, Slack DN, Sloane JP. Intravascular malignant lymphomatosis (angiotropic large-cell lymphoma). A case report with evidence for T-cell lineage with polymerase chain reaction analysis. Histopathology 1994;25:283-6.

13. Harris NL, Jaffe ES, Stein H, Banks PM, Chan JK, Cleary ML, et al. A revised European-American classification of lymphoid neoplasms: a proposal from the International Lymphoma Study Group. Blood 1994;84:1361-92.

14. Willemze R, Kerl H, Sterry W, Berti E, Cerroni L, Chimenti S, et al. EORTC classification for primary cutaneous lymphomas: a proposal from the Cutaneous Lymphoma Study Group of the European Organization for Research and Treatment of Cancer. Blood 1997;90:354-71.

15. Harris NL, Jaffe ES, Diebold J, Flandrin G, Muller-Hermelink HK, Vardiman J, et al. World Health Organization classification of neoplastic diseases of the hematopoietic and lymphoid tissues: report of the Clinical Advisory Committee meeting-Airlie House, Virginia, November 1997. J Clin Oncol 1999;17:3835-49.

16. Wick MR, Mills SE. Intravascular lymphomatosis: clinicopathologic features and differential diagnosis. Semin Diagn Pathol 1991;8:91-101.

17. Suzumiya J, Ohshima K, Kanda M, Kato A, Shuuda K, Kimura $\mathrm{N}$, et al. Intravascular large cell lymphoma associated with hypoalbuminemia. Leuk Lymphoma 1998;32:179-82.

18. DiGiuseppe JA, Nelson WG, Seifter EJ, Boitnott JK, Mann RB. Intravascular lymphomatosis: a clinicopathologic study of 10 cases and assessment of response to chemotherapy. J Clin Oncol 1994;12:2573-9.

19. Lopez-Gil F, Roura M, Umbert I, Umbert P. Malignant proliferative angioendotheliomatosis or angiotropic lymphoma associated with a soft-tissue lymphoma. J Am Acad Dermatol 1992;26:101-4.

20. Sheibani K, Battifora H, Winberg CD, Burke JS, Ben Ezra J, Ellinger GM, et al. Further evidence that malignant angioendotheliomatosis is an angiotropic large-cell lymphoma. N Engl J Med 1986;314:943-8.

21. Snowden JA, Angel CA, Winfield DA, Pringle JH, West KP. Angiotropic lymphoma: report of a case with histiocytic features. J Clin Pathol 1997;50:67-70.

22. O'Grady JT, Shahidullah H, Doherty VR, al Nafussi A. Intravascular histiocytosis. Histopathology 1994;24:265-8.

23. Carter DK, Batts KP, de Groen PC, Kurtin PJ. Angiotropic large cell lymphoma (intravascular lymphomatosis) occurring after follicular small cleaved cell lymphoma. Mayo Clin Proc 1996;71:869-73. 
24. Prayson RA, Segal GH, Stoler MH, Licata AA, Tubbs RR. Angiotropic large-cell lymphoma in a patient with adrenal insufficiency. Arch Pathol Lab Med 1991;115:1039-41.

25. Prayson RA. Angiotropic large cell lymphoma: simultaneous peripheral nerve and skeletal muscle involvement. Pathology 1996;28:25-7.

26. Ormsby A, Prayson RA, Heard R. Angiotrophic large cell lymphoma mimicking multiple sclerosis associated transverse myelitis. J Clin Neurosci 1999;6:408-10.

27. Petroff N, Koger OW, Fleming MG, Fishleder A, Bergfeld WF, Tuthill R, et al. Malignant angioendotheliomatosis: an angiotropic lymphoma. J Am Acad Dermatol 1989;21:72733.

28. Yang B, Tubbs RR, Finn W, Carlson A, Pettay J, Hsi ED. Clinicopathologic reassessment of primary cutaneous B-cell lymphomas with immunophenotypic and molecular genetic characterization. Am J Surg Pathol 2000;24:694-702.

29. Hsi ED, Singleton TP, Swinnen L, Dunphy CH, Alkan S. Mucosa-associated lymphoid tissue-type lymphomas occurring in post-transplantation patients. Am J Surg Pathol 2000; 24:100-6.

30. Segal GH, Jorgensen T, Masih AS, Braylan RC. Optimal primer selection for clonality assessment by polymerase chain reaction analysis: I. Low grade B-cell lymphoproliferative disorders of nonfollicular center cell type. Hum Pathol 1994;25:1269-75.

31. Glass J, Hochberg FH, Miller DC. Intravascular lymphomatosis. A systemic disease with neurologic manifestations. Cancer 1993;71:3156-64.

32. Ferry JA, Harris NL, Picker LJ, Weinberg DS, Rosales RK, Tapia J, et al. Intravascular lymphomatosis (malignant angioendotheliomatosis). A B-cell neoplasm expressing surface homing receptors. Mod Pathol 1988;1:444-52.

33. Mori S, Itoyama S, Mohri N, Shibuya A, Hirose T, Takanashi $\mathrm{R}$, et al. Cellular characteristics of neoplastic angioendotheliosis. An immunohistological marker study of 6 cases. Virchows Arch A Pathol Anat Histopathol 1985;407:167-75.

34. Murase T, Nakamura S, Tashiro K, Suchi T, Hiraga J, Hayasaki N, et al. Malignant histiocytosis-like B-cell lymphoma, a distinct pathologic variant of intravascular lymphomatosis: a report of five cases and review of the literature. $\mathrm{Br}$ Haematol 1997;99:656-64.

35. Stroup RM, Sheibani K, Moncada A, Purdy LJ, Battifora H. Angiotropic (intravascular) large cell lymphoma. A clinicopathologic study of seven cases with unique clinical presentations. Cancer 1990;66:1781-8.

36. Domizio P, Hall PA, Cotter F, Amiel S, Tucker J, Besser GM et al. Angiotropic large cell lymphoma (ALCL): morphological, immunohistochemical and genotypic studies with analysis of previous reports. Hematol Oncol 1989;7:195-206.

37. Ponzoni M, Arrigoni G, Gould VE, Del Curto B, Maggioni M, Scapinello A, et al. Lack of CD 29 (betal integrin) and CD 54 (ICAM-1) adhesion molecules in intravascular lymphomatosis. Hum Pathol 2000;31:220-6.

38. Sepp N, Schuler G, Romani N, Geissler D, Gattringer C, Burg $\mathrm{G}$, et al. Intravascular lymphomatosis (angioendotheliomatosis): evidence for a T-cell origin in two cases. Hum Pathol 1990;21:1051-8.

39. Setoyama M, Mizoguchi S, Orikawa T, Tashiro M. A case of intravascular malignant lymphomatosis (angiotropic large-cell lymphoma) presenting memory $\mathrm{T}$ cell phenotype and its expression of adhesion molecules. J Dermatol 1992;19:263-9.

40. Tateyama H, Eimoto T, Tada T, Kamiya M, Fujiyoshi Y, Kajiura S. Congenital angiotropic lymphoma (intravascular lymphomatosis) of the T-cell type. Cancer 1991;67:2131-6.

41. Gascoyne RD, Adomat SA, Krajewski S, Krajewska M, Horsman DE, Tolcher AW, et al. Prognostic significance of Bcl-2 protein expression and Bcl-2 gene rearrangement in diffuse aggressive non-Hodgkin's lymphoma. Blood 1997;90:24451

42. Lai R, Arber DA, Chang KL, Wilson CS, Weiss LM. Frequency of bcl-2 expression in non-Hodgkin's lymphoma: a study of 778 cases with comparison of marginal zone lymphoma and monocytoid B-cell hyperplasia. Mod Pathol 1998;11:864-9.

43. Skinnider BF, Horsman DE, Dupuis B, Gascoyne RD. Bcl-6 and Bcl-2 protein expression in diffuse large B-cell lymphoma and follicular lymphoma: correlation with 3q27 and 18q21 chromosomal abnormalities. Hum Pathol 1999;30:803-8.

44. Raible MD, Hsi ED, Alkan S. Bcl-6 protein expression by follicle center lymphomas. A marker for differentiating follicle center lymphomas from other low-grade lymphoproliferative disorders. Am J Clin Pathol 1999;112:101-7.

45. Pittaluga S, Ayoubi TA, Wlodarska I, Stul M, Cassiman JJ, Mecucci C, et al. BCL-6 expression in reactive lymphoid tissue and in B-cell non-Hodgkin's lymphomas. J Pathol 1996;179:145-50.

46. Onizuka T, Moriyama M, Yamochi T, Kuroda T, Kazama A, Kanazawa N, et al. BCL-6 gene product, a 92-to 98-kD nuclear phosphoprotein, is highly expressed in germinal center B cells and their neoplastic counterparts. Blood 1995;86:2837.

47. Omonishi K, Yoshino T, Sakuma I, Kobayashi K, Moriyama M, Akagi T. bcl-6 protein is identified in high-grade but not low-grade mucosa-associated lymphoid tissue lymphomas of the stomach. Mod Pathol 1998;11:181-5.

48. Harada S, Suzuki R, Uehira K, Yatabe Y, Kagami Y, Ogura M, et al. Molecular and immunological dissection of diffuse large B cell lymphoma: CD5+, and CD5- with CD10+ groups may constitute clinically relevant subtypes. Leukemia 1999;13:1441-7.

49. Zhang A, Ohshima K, Sato K, Kanda M, Suzumiya J, Shimazaki K, et al. Prognostic clinicopathologic factors, including immunologic expression in diffuse large B-cell lymphomas. Pathol Int 1999;49:1043-52.

50. Yamaguchi M, Ohno T, Oka K, Taniguchi M, Ito M, Kita K, et al. De novo CD5-positive diffuse large B-cell lymphoma: clinical characteristics and therapeutic outcome. $\mathrm{Br} J$ Haematol 1999;105:1133-9.

51. Bene MC, Castoldi G, Knapp W, Ludwig WD, Matutes E, Orfao A, et al. Proposals for the immunological classification of acute leukemias. European Group for the Immunological Characterization of Leukemias (EGIL). Leukemia 1995;9:1783-6.

52. Schmidt CJ, Domenico L, Ward P, Barcos MP, Stewart CC. Aberrant antigen expression detected by multiparameter three color flow cytometry in intermediate and high grade B-cell lymphomas. Leuk Lymphoma 1999;34:539-44.

53. Bergmann M, Blasius S, Bankfalvi A, Mellin W. Primary non-Hodgkin lymphomas of the CNS-proliferation, oncoproteins and Epstein-Barr-virus. Gen Diagn Pathol 1996; 141:235-42.

54. Au WY, Shek TW, Kwong YL. Epstein-Barr virus-related intravascular lymphomatosis. Am J Surg Pathol 2000;24:30910 .

55. Au WY, Shek WH, Nicholls J, Tse KM, Todd D, Kwong YL. T-cell intravascular lymphomatosis (angiotropic large cell lymphoma): association with Epstein-Barr viral infection. Histopathology 1997;31:563-7.

56. Hsiao CH, Su IJ, Hsieh SW, Huang SF, Tsai TF, Chen MY, et al. Epstein-Barr virus-associated intravascular lymphomatosis within Kaposi's sarcoma in an AIDS patient. Am J Surg Pathol 1999;23:482-7. 
57. Bogomolski-Yahalom V, Lossos IS, Okun E, Sherman Y, Lossos A, Polliack A. Intravascular lymphomatosis-an indolent or aggressive entity? Leuk Lymphoma 1998; 29:585-93.

58. Kayano H, Katayama I. Primary hepatic lymphoma presenting as intravascular lymphomatosis. Arch Pathol Lab Med 1990;114:580-4.

59. de Jong D, Van Gorp J, Sie-Go D, Van Heerde P. T-cell rich b-cell non-hodgkin's lymphoma: a progressed form of follicle centre cell lymphoma and lymphocyte predominance hodgkin's disease. Histopathology 1996;28:15-24.
60. Calamia KT, Miller A, Shuster EA, Perniciaro C, Menke DM. Intravascular lymphomatosis. A report of ten patients with central nervous system involvement and a review of the disease process. Adv Exp Med Biol 1999;455:249-65.

61. Rose C, Staumont D, Jouet JP. Successful autologous bone marrow transplantation in intravascular lymphomatosis. Br J Haematol 1999;105:313-4.

62. Chang A, Zic JA, Boyd AS. Intravascular large cell lymphoma: a patient with asymptomatic purpuric patches and a chronic clinical course. J Am Acad Dermatol 1998;39:318-21. 